\author{
George C. L. Bezerra \\ University of Coimbra \\ School of Economics \\ Av. Dias da Silva 165 \\ 3004-512 Coimbra - Portugal \\ Tel: +351 239790588 \\ Email: george.bezerra@student.uc.pt \\ Carlos F. Gomes \\ University of Coimbra \\ School of Economics \\ ISR-Institute of Systems and Robotics \\ Av. Dias da Silva 165 \\ 3004-512 Coimbra - Portugal \\ Tel: +351 239790588 \\ Email: cfgomes@fe.uc.pt
}

This is a post-print (i.e. final draft post-refereeing) of an article published in Journal of Air Transport Management, available online at:

https://doi.org/10.1016/j.jairtraman.2016.02.001.

Citation: Bezerra, G.C.L., \& Gomes, C.F. (2016) “Measuring Airport Service Quality: A Multidimensional Approach", Journal of Air Transport Management, 53, pp. 8593, http://dx.doi.org/10.1016/i.jairtraman.2016.02.001. 
Bezerra, G.C.L., \& Gomes, C.F. (2015) “Measuring airport service quality: a multidimensional approach", Journal of Air Transport Management, 53, pp. 85-93, http://dx.doi.org/10.1016/j.jairtraman.2016.02.001.

\title{
Measuring Airport Service Quality: A Multidimensional Approach
}

\begin{abstract}
:
Currently, airports are expected to be operated as self-sufficient service organizations providing efficient and high-quality services to different customers. In this context, improving airport service quality (ASQ) has become paramount. However, due to the complexity of the airport service environment, an effective process of measuring and analyzing passengers' perceptions of ASQ is not simply achieved. Generic scales for perceived service quality might not cover some particularities of the passenger-airport interaction. Furthermore, while some measurement practices have been developed within the airport industry, there was only limited consideration for validity and reliability. These concerns are certainly relevant to avoid misapprehension of passengers' perceptions. In view of that, this paper has a twofold objective. First, to fit a measurement model for perceived ASQ built on typical service measures within the airport industry. Second, to test for the model equivalence across groups of passengers. Sample data from an extensive survey applied at a main Brazilian airport was used for confirmatory factor analysis. The results suggested that a six-factor structure provides a meaningful multi-item measurement model for perceived ASQ. The model was validated for international and domestic departing passengers as regards its factorial structure and metric invariance. The proposed measurement model could be considered an alternative for a multidimensional approach in the context of airport performance measurement as regards service quality. Finally, the findings arising from this research might contribute to the discussion on passengers' perceptions of ASQ, particularly concerning its multidimensionality and the need for reviewing current practices for ASQ analysis.
\end{abstract}

Keywords: Airport service quality; Service quality measurement; Service quality multidimensionality; Confirmatory factor analysis; Airport performance. 
Bezerra, G.C.L., \& Gomes, C.F. (2015) “Measuring airport service quality: a multidimensional approach", Journal of Air Transport Management, 53, pp. 85-93, http://dx.doi.org/10.1016/j.jairtraman.2016.02.001.

\section{INTRODUCTION}

As traffic volume rises, airports struggle for optimizing infrastructure while adopting a customer-orientation focus to achieve better performance (Fodness \& Murray, 2007; Halpern \& Graham, 2013). Also, non-aeronautical revenues have become critical for airport sustainability, which leads to increasing concerns with the marketing of retail areas within airport terminals (Gillen, 2011). Therefore, the relevance of understanding passengers' perceptions of airport service quality (ASQ) is paramount.

Within the airport industry, service quality measures based on passenger perception have been used typically for operational performance measurement and benchmarking purposes. Moreover, regulators and governments might use service quality monitoring to assure that the interests of airport users are not being compromised (Francis, Humphreys, \& Fry, 2002). With the growing interest on the subject, ASQ surveys have been systematically carried out by international agencies, regulatory authorities, airport operators, and other organizations (ACl, 2014; Fodness \& Murray, 2007; IATA, 2015; Kramer, Bothner, \& Spiro, 2013; Zidarova \& Zografos, 2011).

More recently, some approaches and methods usually applied within other industries appeared to have gained momentum. For instance, analysis of passenger's expectations as regards the airport service and using structural equation modeling approach for the complex relationships among passenger's attitude and ASQ (Bogicevic, Yang, Bilgihan, \& Bujisic, 2013; Fodness \& Murray, 2007; Jeon \& Kim, 2012; Nesset \& Helgesen, 2014; Park \& Jung, 2011). It 
Bezerra, G.C.L., \& Gomes, C.F. (2015) “Measuring airport service quality: a multidimensional approach", Journal of Air Transport Management, 53, pp. 85-93, http://dx.doi.org/10.1016/j.jairtraman.2016.02.001.

seems that there is increasing interest in understanding ASQ multidimensionality and the multifaceted nature of the passenger-airport interaction.

Notwithstanding, due to the complexity of the airport service environment, an effective process of measuring and analyzing relevant information as regards passengers' perceptions of ASQ is not simply achieved. Generic service quality measurement approaches might not be able to cover more particular aspects of the passenger interaction with the airport services and facilities (George, Henthorne, \& Panko, 2013; Pantouvakis, 2010). Otherwise, current practices within the airport industry have been usually based on the service attribute level with none or only limited consideration for the validity and reliability of the measurement instruments.

In this context, the objective of this paper is twofold. First, to fit a measurement model for perceived ASQ based on typical service quality measures within the airport industry. Second, testing for the equivalence of the proposed model across groups of passengers. This present paper is part of an extensive research project accounting for the multidimensionality of ASQ and its monitoring in the context of airport performance measurement. The relevance of these objectives is related to avoiding misinterpretation of the results arising from service quality surveys within the performance measurement process.

Sample data from a survey applied to departing passengers at Guarulhos International Airport, in Brazil, was used. Confirmatory factor analysis was used to test for the factorial validity of an ASQ framework based on a previous exploratory study of Bezerra \& Gomes (2015) and for 
Bezerra, G.C.L., \& Gomes, C.F. (2015) “Measuring airport service quality: a multidimensional approach", Journal of Air Transport Management, 53, pp. 85-93, http://dx.doi.org/10.1016/j.jairtraman.2016.02.001.

model specification. Afterward, invariance of the measurement instrument was tested across groups of international and domestic departing passengers.

In the next section, a background on ASQ is provided, including the evolution of the research and current challenges. In the methods section, the sample characteristics, data collection, research procedures, models, and variables are described. Results and discussions on the findings are provided subsequently. Finally, the concluding remarks section outlines the contributions of this research effort and considerations for future research.

\section{BACKGROUND}

Airport Service Quality (ASQ) has become a usual topic within the airport-related literature. Nonetheless, until the 1980 's there were few studies related to the subject, typically concerned with the assessment of the level of service in the passenger terminal (e.g. Bennets, Hawkins, McGinity, O’Leary, \& Ashford, 1975; Mumayiz \& Ashford, 1986; Omer \& Khan, 1988; Tosic \& Babic, 1984). Later, in the 1990 's, some studies focused on understanding passengers' needs and their perceptions regarding elements of the passenger terminal and airport-related processes (e.g. Hackett \& Foxall, 1997; Lemer, 1992; Muller \& Gosling, 1991; Mumayiz, 1991; Park, 1999; Seneviratne \& Martel, 1991, 1994; Yen, 1995).

Regarding the service industry as a whole, in a constantly changing business environment understanding customer perception of quality became critical. As the perceived level of quality is an antecedent of customer satisfaction with the service performance, measuring service quality by customer-based variables may lead organization's efforts to better deal with customers' needs (Cronin, Brady, \& Hult, 2000; Falk, Hammerschmidt, \& Schepers, 2010; 
Bezerra, G.C.L., \& Gomes, C.F. (2015) “Measuring airport service quality: a multidimensional approach", Journal of Air Transport Management, 53, pp. 85-93, http://dx.doi.org/10.1016/j.jairtraman.2016.02.001.

Wilson, Zeithaml, Bitner, \& Gremler, 2012).

In this context, the airport industry has been progressively motivated to adopt a different approach regarding ASQ. The literature enlarged in terms of quantity and the range of issues covered. Hence, a broader approach to ASQ based on passenger perception became more evident, including:

a. Further investigation of passenger perception of quality and his/her level of satisfaction with different airport service attributes. Some studies based on econometric approaches (e.g. Correia, Wirasinghe, \& de Barros, 2008a; Correia \& Wirasinghe, 2007; De Barros, Somasundaraswaran, \& Wirasinghe, 2007; Eboli \& Mazzulla, 2009; Gkritza, Niemeier, \& Mannering, 2006), and others based on Multi-Criteria Decision Analysis (MCDA) tools (e.g. Chien-Chang, 2012; Kuo \& Liang, 2011; Lupo, 2015; Tsai, Hsu, \& Chou, 2011; Yeh \& Kuo, 2003);

b. Resuming investigation on passenger expectations with the airport service (Bogicevic et al., 2013; Caves \& Pickard, 2000; Chang \& Chen, 2011, 2012; Fodness \& Murray, 2007; George et al., 2013; Rhoades, Waguespack Jr, \& Young, 2000);

c. The nature of the effects of different service attributes on passenger satisfaction with the airport (Bogicevic et al., 2013; Mikulic \& Prebežac, 2008; Prebezac, Mikulic, \& Jurkovic, 2010);

d. Discussions on service quality measurement, including exploratory studies on ASQ multidimensionality (Bezerra \& Gomes, 2015; Fodness \& Murray, 2007; George et al., 2013);

e. Accounting for service quality within studies on airport efficiency measurement 
Bezerra, G.C.L., \& Gomes, C.F. (2015) “Measuring airport service quality: a multidimensional approach", Journal of Air Transport Management, 53, pp. 85-93, http://dx.doi.org/10.1016/j.jairtraman.2016.02.001.

(De Nicola, Gitto, \& Mancuso, 2013; Merkert \& Assaf, 2015).

Also, there is a growing interest on structural equation modeling (SEM) approach to account for the complex relationships among the several aspects of service quality and passenger attitude (Fodness \& Murray, 2007; Jen, Lancaster, Hsieh, Wu, \& Chan, 2013; Jeon \& Kim, 2012; Lubbe, Douglas, \& Zambellis, 2011; Nesset \& Helgesen, 2014; Park \& Jung, 2011). It appears that a more comprehensive approach to understanding the multidimensionality of ASQ and the multifaceted nature of the passenger-airport interaction has been pursued.

Due to the complexity of airport settings, however, generic scales for measuring perceived service quality may not be able to cover some specific features related to the airport services and facilities (George et al., 2013; Pantouvakis, 2010). Based on a functional approach, a passenger terminal system comprises three major areas: access interface, processing area and flight interface (Horonjeff et al., 2010). The processing area, focus of the present study, comprises every space where the passenger is processed in any activity related to the starting, ending, or continuation of the trip (e.g. ticketing, check-in, security inspection, etc.).

According to the passenger's point of view, two main categories of activities in airport terminal may be considered: process activities and discretionary activities (Popovic et al., 2009; Caves \& Pickard, 2000). In the case of departing passengers, process activities comprise the passenger flow from check-in, security screening, until boarding. The discretionary activities comprise what the passengers are able to do at their slack time in the terminal (i.e. that moments when they are moving between processing points), when they can shop, eat, rest, exchange money, or any other activity provided by the airport. 
Bezerra, G.C.L., \& Gomes, C.F. (2015) “Measuring airport service quality: a multidimensional approach", Journal of Air Transport Management, 53, pp. 85-93, http://dx.doi.org/10.1016/j.jairtraman.2016.02.001.

As regards the processing activities, passenger perception of quality has been traditionally associated with the efficiency of the processes, short waiting times and the positive attitude of the service staff (Caves \& Pickard, 2000; Fodness \& Murray, 2007; Rhoades et al., 2000). With reference to the discretionary activities, a variety of factors should be considered, including passenger's perception on leisure/convenience alternatives and airport servicescape, i.e. the physical setting in which a service is performed, delivered, and consumed (Bitner, 1992; Bogicevic et al., 2013; Mari \& Poggesi, 2011).

Regarding the current ASQ measurement practices, the literature review undertaken in this study revealed a focus on analysis at the service-attribute level, with data collection based on surveys. Common measures include items related to the efficiency of specific services or processes, signage and cleanliness of terminal areas, attitude of the staff, and availability of convenience facilities, among several others. Additionally, as an elaborate servicescape, an airport comprises a complex service environment, in which visual appeal, functionality, and comfort might affect passenger perception of service quality. The effects of airport physical surroundings on passengers' perceptions of ASQ has been more recently discussed (Fodness \& Murray, 2007; Jen et al., 2013; Jeon \& Kim, 2012; Bogicevic et al., 2013).

In spite of systematic practices within the airport industry (ACl, 2014; IATA, 2015; Kramer et al., 2013; Zidarova \& Zografos, 2011), usually, they have been more concerned with contextspecific purposes and considerations on the reliability and validity aspects of the measurement instrument have received only limited attention (George et al., 2013).

Overall, it seems that there is an increasing acknowledgment of the multidimensionality of 
ASQ. Studies previously referred have stressed passenger perception according to a multidimensional approach and some factorial structures for measuring ASQ have been discussed. However, there is still the need for further investigation on the validity and reliability of service quality measurement in the airport setting. The relevance of such concerns is paramount to avoiding misapprehension of passengers' perceptions and guiding the use of surveys within the performance measurement process.

\section{METHODS}

\subsection{Sample and Data Collection}

Data was obtained from a survey applied to passengers at Guarulhos International Airport, in Brazil. Data was collected from January to December of 2014 at the departure lounges during airport peak hours to gather passengers' opinion at a moment of high demand (SAC, 2015). Contacting passengers at the departure lounge assures that they have already had the opportunity to experience the services, processes, and facilities.

A total of 2,485 forms were collected from departing passengers. As sample size was large enough to proceed with the proposed multivariate techniques, missing value treatment was listwise exclusion (Byrne, 2010; Hair, Black, Babin, \& Anderson, 2009). Therefore, the useful sample comprised 1,155 observations, 762 passengers of international flights and 393 passengers departing on domestic flights. 
Bezerra, G.C.L., \& Gomes, C.F. (2015) “Measuring airport service quality: a multidimensional approach", Journal of Air Transport Management, 53, pp. 85-93, http://dx.doi.org/10.1016/j.jairtraman.2016.02.001.

The sample of international passengers was used for testing for factorial validity and model specification. The sample of domestic passengers was used for testing for the equivalence of the measurement model. The relevance of this approach relies on the fact that international and domestic passengers may have different interaction and behavioral patterns during as regards their experience with the airport.

Normality was assessed by Skewness and Kurtosis coefficients. Mahalanobis distance squared was used for outlier identification and 40 observations were excluded from the sample of international passengers. The sample characteristics are presented in Appendix A.

As regards the research instrument, the original set of measurement items comprised typical attributes related to services/processes performance and airport terminal facilities. Items are aligned to industry best practice guidelines (ACI, 2014; IATA, 2015) and are similar to several previous research studies (Correia, Wirasinghe, \& de Barros, 2008b; Kramer et al., 2013; Park \& Jung, 2011; Yeh \& Kuo, 2003). Passengers indicated their opinion by rating on a five-point scale.

This present study focused on those aspects directly or indirectly related to airport management regarding the passenger terminal as previously considered by Bezerra \& Gomes (2015). Table 1 presents the descriptive statistics for the measurement items.

[Insert Table 1 here] 


\subsection{Models, Variables and Data Analysis}

Bezerra and Gomes (2015) used exploratory factor analysis (EFA) to extract service quality factors from a set of typical attributes within the airport industry, based on responses of international departing passengers at Guarulhos International Airport, in Brazil. A proposed ASQ framework comprised seven factors representative of the passenger's perception on airport services and facilities.

In the present paper, the factorial validity of this ASQ framework was tested using a new sample of international departing passengers from the same airport. Table 2 summarizes the variables and respective service quality factors, along with the Cronbach's alpha values for each factor and results supporting factor unidimensionality obtained from EFA.

[Insert Table 2 here]

Sample data was assessed on the existence of common method bias by Harman's single factor test and the common latent factor approach (Podsakoff, MacKenzie, Lee, \& Podsakoff, 2003). According to the tests, there was no indication of significant concerns regarding common method variance.

Provided with these results, CFA models were estimated with the software IBM AMOS, version 21. The 23 observed variables were assumed to load only on the respective factor. The seven factors were assumed to be intercorrelated while the errors of measurement of the observed variables to be uncorrelated. The models were estimated by the maximum likelihood method (Byrne, 2010). Validity and reliability were assessed according to Fornell and Larcker (1981). 
Bezerra, G.C.L., \& Gomes, C.F. (2015) “Measuring airport service quality: a multidimensional approach", Journal of Air Transport Management, 53, pp. 85-93, http://dx.doi.org/10.1016/j.jairtraman.2016.02.001.

Models' goodness of fit was evaluated consistent with references of Byrne (2010) and Hair et al. (2009).

\section{RESULTS AND DISCUSSION}

\subsection{Testing for the Factorial Validity and Model Specification}

Overall, a first model revealed an acceptable goodness-of-fit $(\mathrm{CMIN} / \mathrm{df}=4.688 ; \mathrm{GFI}=.889$, PGFI=.673, CFI=.941, PCFI=.778; RMSEA=.072). All the regression weights presented positive signs and statistical significance ( $p$-value $<.001$ level).

However, examining the items reliability, the variable CHK3 (Availability of luggage carts) presented a low value for square multiple correlation. Only about $25 \%$ of its variance was explained by the factor Check-in. Also, its standardized regression weight was much lower (.501) comparing with the other variables reflecting the factor (>.800). Along with the itemtotal correlation presented in table 3 , these results indicated the exclusion of this variable and may suggest that passengers do not perceive the availability of luggage carts necessarily related to the quality of the check-in process.

As regards construct validity and reliability, there were significant concerns related to the factor Prices. The composite reliability $(C R=.65)$ and the average variance extracted $(A V E=.482)$ might indicated reliability and convergent validity issues. The squared AVE was less than the absolute value of the correlation with the factor Convenience ( $r=.848)$, indicating revealing no sufficient discriminant validity for this factor. 
Bezerra, G.C.L., \& Gomes, C.F. (2015) “Measuring airport service quality: a multidimensional approach", Journal of Air Transport Management, 53, pp. 85-93, http://dx.doi.org/10.1016/j.jairtraman.2016.02.001.

Customers usually evaluate prices based on their perception of value as regards the service performed (Cronin et al., 2000; Gordon \& Levesque, 2000; Ravald \& Grönroos, 1996), which may explain the strong correlation and the lacking of discriminant validity. These results supported that the passenger perception of the prices practiced in the retail area should be considered as a different construct in a customer satisfaction model (i.e. perceived value) (Anderson \& Fornell, 2000; Chen, 2008).

In view of the results and the theoretical and practical issues, we have concluded for misspecification of the initial model and excluded factor Prices and variable $\mathrm{CHK} 3$ from the following analyzes. Subsequently, a second model presented goodness-of-fit improvement $(\mathrm{CMIN} / \mathrm{df}=4.539 ; \mathrm{GFI}=.907, \mathrm{PGFI}=.669, \mathrm{CFI}=.955, \mathrm{PCFI}=.779 ; \mathrm{RMSEA}=.070)$. No validity or reliability issues were identified.

For the purpose of measurement model specification, we examined the standardized residual covariance (SRC). The only concern was variable CON1 with 15 out of 20 residuals higher than the threshold of 2.58 (Byrne, 2010). Moreover, the modification indices indicated that this variable might present significant cross-loadings to the other five factors. Although passenger opinion about staff attitude (in this case, excluding check-in and security processes) is indeed important for understanding his/her perception of ASQ, it seems that item wording might not be sufficiently discriminant and passengers should have led to considering different groups of staff, such as retail stores, food facilities, information desks, etc. Hence, we decided for excluding this variable and no significant SRC or modification indices remained. 
A six-factor model excluding factor Prices and variables $\mathrm{CHK} 3$ and CON1 presented a much better factor structure and goodness-of-fit. Hence, there was no justification for any further model fitting (CMIN/df=3.607; RMSEA=.060; GFI=.932; PGFI=.672; CFI=.969; PCFI=.777). The expected cross-validation index for maximum likelihood estimation was much smaller $(M E C V I=.837)$ than the initial model (MECVI=1.551). The item reliability was confirmed by the values for square multiple correlations (all above .40). Factorial validity and reliability were confirmed (Table 3).

[Insert Table 3 here]

\subsection{ASQ Measurement model}

The figure 1 presents the model structure along with the output for international departing passengers, including the standardized estimates for regression weights and correlations. The relationships among the observed variables and the respective factors were statistically significant ( $p$-value<.001). The standardized weights were reasonably high.

[Insert Figure 1 here]

This six-factor model covers relevant issues related to the airport services and facilities as perceived by the passengers and may provide a comprehensive approach to the service quality measurement in the airport context. A brief description of the ASQ factors is provided in Appendix B. 
Bezerra, G.C.L., \& Gomes, C.F. (2015) “Measuring airport service quality: a multidimensional approach", Journal of Air Transport Management, 53, pp. 85-93, http://dx.doi.org/10.1016/j.jairtraman.2016.02.001.

After these procedures, the equivalence of this factor structure and its metric invariance across groups of international and domestic passengers were tested. Testing for the equivalence or invariance is needed to examine the suitability of the model for different groups of passengers.

\subsection{Testing for the Equivalence of the Measurement Model}

A CFA model consistent with Figure 1 was estimated with the sample of domestic departing passengers. The results indicated good fit $(\mathrm{CMIN} / \mathrm{df}=2.197 ; \mathrm{RMSEA}=.055 ; \mathrm{GFI}=.926 ; \mathrm{PGFI}=.668$; $\mathrm{CFI}=.960 ; \mathrm{PCFI}=.769)$. Regression weights and covariances were statistically significant. Item reliability was confirmed by the square multiple correlations. No validity or reliability concerns were identified.

The standardized regression weights and correlations estimated with this model are presented in Appendix C, along with the respective values for international passengers (Tables C.1 and C.2). Provided with these results, the baseline model for both groups were assumed to be the same and configural invariance was assessed. The configural model presented good fit (CMIN/df=2.092; RMSEA=.041; GFI=.930; PGFI=.671; CFI=.967; PCFI=.775). Hence, the factor structure was considered equivalent across groups, i.e. the measurement items were properly explained for their respective factors, no matter the respondent is an international or domestic passenger. 
Afterwards, the metric invariance was tested. Domestic and international passengers served as distinct groups for multi-group analysis based on the comparison of that configural model (unconstrained) and two constrained models:

Model 1: The factor loadings constrained to be equal.

Model 2: Both factor loadings and covariances among factors constrained to be equal.

In testing for metric invariance, two approaches were followed. The $\chi^{2}$ difference between the comparing models $\left(\Delta \chi^{2}\right)$, and the difference in the CFI $(\Delta C F I)$. The former is considered to be excessively stringent, while the latter is reported to make more practical sense (Byrne, 2010; Cheung \& Rensvold, 2002). The values for $\chi^{2}$ (CMIN) and CFI for the three models are presented in table 4.

[Insert Table 4 here]

The differences between model 1 and the unconstrained model were $\Delta \chi^{2}(13)=54.112$ ( $p$ value<.001) and $\Delta \mathrm{CFI}=.003$. As regards model $2, \Delta \chi^{2}(28)=85.601(\mathrm{p}$-value $<.001)$ and $\Delta C F I=.004$. Based on the $\triangle \mathrm{CFI}$ tests, these results suggest invariance across the groups of international and domestic passengers (Cheung \& Rensvold, 2002). However, with the $\Delta \chi^{2}$ being statistically significant, we focused on identifying which parameters might have been contributing to the partial invariance specified by the $\Delta \chi^{2}$ tests. The progressive strategy based on the $\chi^{2}$ difference was followed (Byrne, 2010).

Only the variables CON2 (availability and quality of stores), AMB1 (cleanliness of airport facilities), and MOB2 (wayfinding) presented a significant difference between groups. These 
Bezerra, G.C.L., \& Gomes, C.F. (2015) “Measuring airport service quality: a multidimensional approach", Journal of Air Transport Management, 53, pp. 85-93, http://dx.doi.org/10.1016/j.jairtraman.2016.02.001.

findings mean that the items are operating somewhat differently for international and domestic passengers. This might be related to the differences in the interaction and behavioral patterns of each group of passengers. For instance, usually international passengers may carry more luggage and they are asked to arrive at the airport with more antecedence prior to the flight departure time. Passengers with more luggage are usually more awkward for moving within the terminal and check points (Barros \& Tomber, 2007). The effect of the amount of time spent in the airport on passenger perception has already been stressed (Bezerra \& Gomes, 2015; Crawford \& Melewar, 2003). Moreover, there may be substantial difference between domestic and international areas/terminals as regards retail area and convenience facilities within the airport setting.

As regards the covariances, only the covariance between factors check-in and basic facilities were nonequivalent. This covariance had no statistical significance for the group of international passengers while it was significant for domestic passengers. This parameter estimate was low for both groups, which was expected as the variables measuring each factor are quite independent.

In summary, accounting for: a. existence of configural invariance between groups; $b$. indication of equivalence provided by the $\Delta \mathrm{CFI}$ tests; and c. the nonequivalent parameters identified by $\Delta \times 2$ are just a small number within the measurement model (no more than one per factor); it is reasonable to assume that the partial invariance identified by the $\Delta \chi 2$ tests does not compromise the suitability of the model for both groups of passenger and should not inhibit the use of the measurement model (Cheung \& Rensvold, 2002; Sass, 2011). 


\section{CONCLUSIONS}

An effective airport service quality (ASQ) measurement is a relevant issue for practitioners and researchers. Although measurement practices are common within the airport industry, little attention has been given to the validity and reliability of the measurement instruments. Focusing on this gap, we aimed to fit a measurement model for perceived ASQ and afterwards to test for its equivalence across groups of passengers.

The results suggested that a six-factor model based on typical measures within the airport industry may provide a meaningful multi-item instrument for measuring passenger's perception of ASQ. The measurement items were explained properly for their respective service quality factors; no matter the respondent was an international or domestic departing passenger.

As airports are complex service settings, generic approaches for measuring service quality might not cover some specific characteristics related to the passenger-airport interaction (George et al., 2013; Pantouvakis, 2010). The proposed model covers relevant issues related to the passenger perception as regards ASQ. It comprises the performance of core airport processes (check-in and security screening), along with aspects related to the passengerairport interaction in his/her way through the terminal, leisure/convenience alternatives, and airport servicescape. To be noted that in the airport business dynamics those aspects are closely related. In effect, efficient and reliable processes may result in more relaxed 
Bezerra, G.C.L., \& Gomes, C.F. (2015) “Measuring airport service quality: a multidimensional approach", Journal of Air Transport Management, 53, pp. 85-93, http://dx.doi.org/10.1016/j.jairtraman.2016.02.001.

passengers with more time for discretionary activities and, consequently, more likely to stay and purchase at airport's retail areas (Crawford \& Melewar, 2003; Jeon \& Kim, 2012).

This proposed model may represent a suitable alternative for a more parsimonious and practical analysis of $A S Q$, instead of considering a vast set of items individually. Since the perceived level of quality is an antecedent of passenger satisfaction and his/her attitude as regards the airport, measuring service quality according to this approach may support airport managers and other decision-makers with a passenger-orientation focus for airport planning and management.

This research effort may contribute to a more comprehensive understanding of ASQ as perceived by passengers. Particularly, it stresses the need for reviewing current practices for measuring and analyzing service quality within the airport industry. Changing ASQ analysis from the service-attribute level to a multidimensional approach, as already emphasized, implies to assure for the validity and reliability of the measurement instruments used.

As regards future research, since customer perception is obviously subjective and context dependent, testing for the suitability of this factor-structure in different airport setting is needed. Also, future developments of the measurement model should consider broadening the approach to the airport service environment. For instance, the addition of variables related to the convenience services/facilities and airport servicescape should be very useful, particularly for assessing the effects of the airport environment on passenger purchasing behavior and post-consumption attitude. Finally, concerning the need for extracting the most relevant information as regards ASQ, the airport industry could benefit in great extent from 
Bezerra, G.C.L., \& Gomes, C.F. (2015) “Measuring airport service quality: a multidimensional approach", Journal of Air Transport Management, 53, pp. 85-93, http://dx.doi.org/10.1016/j.jairtraman.2016.02.001.

the advances from other service settings, namely the modeling of the antecedents and consequences of customer satisfaction.

\section{REFERENCES}

ACI, A. C. I. (2014). Airport-Service-Quality/About-ASQ. Retrieved March 25, 2015, from http://www.aci.aero/Airport-Service-Quality/ASQ-Home

Anderson, E. W., \& Fornell, C. (2000). Foundations of the American Customer Satisfaction Index. Journal of Total Quality Management, 11(7), 5869-5882.

Bennets, D., Hawkins, N. M., McGinity, P. D., O’Leary, M., \& Ashford, N. (1975). Survey analysis of airport terminal passenger processing: TT Report No 7502. Loughborough, UK.

Bezerra, G. C. L., \& Gomes, C. F. (2015). The effects of service quality dimensions and passenger characteristics on passenger's overall satisfaction with an airport. Journal of Air Transport Management, 44-45, 77-81.

http://doi.org/10.1016/j.jairtraman.2015.03.001

Bitner, M. J. (1992). Sercivescapes: the impact of physical surroundings on customers and employees. Journal of Marketing, 56(1), 57-71.

Bogicevic, V., Yang, W., Bilgihan, A., \& Bujisic, M. (2013). Airport service quality drivers of passenger satisfaction. Tourism Review, 68(4), 3-18. http://doi.org/10.1108/TR-092013-0047

Byrne, B. M. (2010). Structural equation modeling with AMOS: basic concepts, applications, 
Bezerra, G.C.L., \& Gomes, C.F. (2015) “Measuring airport service quality: a multidimensional approach", Journal of Air Transport Management, 53, pp. 85-93, http://dx.doi.org/10.1016/j.jairtraman.2016.02.001.

and programming (2nd ed.). New York: Routledge, Taylor \& Francis.

Caves, R. E., \& Pickard, C. D. (2000). The satisfaction of human needs in airport passenger terminals. Transport, 147(1), 9-15.

Chang, Y. C., \& Chen, C. F. (2011). Identifying mobility service needs for disabled air passengers. Tourism Management, 32(5), 1214-1217.

http://doi.org/10.1016/j.tourman.2010.11.001

Chang, Y. C., \& Chen, C. F. (2012). Service needs of elderly air passengers. Journal of Air Transport Management, 18(1), 26-29. http://doi.org/10.1016/j.jairtraman.2011.07.002

Chen, C. F. (2008). Investigating structural relationships between service quality, perceived value, satisfaction, and behavioral intentions for air passengers: Evidence from Taiwan. Transportation Research Part A: Policy and Practice, 42(4), 709-717.

Cheung, G. W., \& Rensvold, R. B. (2002). Evaluating goodness-of-fit indexes for testing measurement invariance. Structural Equation Modeling, 9(2), 233-255.

Chien-Chang, C. (2012). Evaluating the quality of airport service using the fuzzy multi-criteria decision-making method: A case study of Taiwanese airports. Expert Systems, 29(3), 246-260. http://doi.org/10.1111/j.1468-0394.2010.00574.x

Correia, A. R., \& Wirasinghe, S. C. (2007). Development of level of service standards for airport facilities: Application to Sao Paulo international airport. Journal of Air Transport Management, 13, 97-103.

Correia, A. R., Wirasinghe, S. C., \& de Barros, A. G. (2008a). A global index for level of service evaluation at airport passenger terminals. Transportation Research Part E: Logistics and Transportation Review, 44(4), 607-620. http://doi.org/10.1016/j.tre.2007.05.009 
Bezerra, G.C.L., \& Gomes, C.F. (2015) “Measuring airport service quality: a multidimensional approach", Journal of Air Transport Management, 53, pp. 85-93, http://dx.doi.org/10.1016/j.jairtraman.2016.02.001.

Correia, A. R., Wirasinghe, S. C., \& de Barros, A. G. (2008b). Overall level of service measures for airport passenger terminals. Transportation Research Part A: Policy and Practice, 42(2), 330-346. http://doi.org/10.1016/j.tra.2007.10.009

Crawford, G., \& Melewar, T. C. (2003). The importance of impulse purchasing behaviour in the international airport environment. Journal of Consumer Behaviour, 3(1), 85-98.

Cronin, J. J. J., Brady, M. K., \& Hult, T. M. (2000). Assessing the effects of quality, value, customer satisfaction on consumer behavioral intentions in service environment. Journal of Retailing, 76(2), 193-218.

De Barros, A. G., Somasundaraswaran, A. K., \& Wirasinghe, S. C. (2007). Evaluation of level of service for transfer passengers at airports. Journal of Air Transport Management, 13(5), 293-298. http://doi.org/10.1016/j.jairtraman.2007.04.004

De Barros, A. G., \& Tomber, D. D. (2007). Quantitative analysis of passenger and baggage security screening at airports. Journal of Advanced Transportation, 41(2), 171-193.

De Nicola, A., Gitto, S., \& Mancuso, P. (2013). Airport quality and productivity changes: A Malmquist index decomposition assessment. Transportation Research Part E: Logistics and Transportation Review, 58, 67-65. http://doi.org/10.1016/j.tre.2013.07.001

Eboli, L., \& Mazzulla, G. (2009). An ordinal logistic regression model for analysing airport passenger satisfaction. EuroMed Journal of Business, 4(1), 40-57. http://doi.org/10.1108/14502190910956684

Falk, T., Hammerschmidt, M., \& Schepers, J. J. L. (2010). The service quality-satisfaction link revisited: exploring asymmetries and dynamics. Journal of the Academy of Marketing Science, 38, 288-302. http://doi.org/10.1007/s11747-009-0152-2 
Bezerra, G.C.L., \& Gomes, C.F. (2015) “Measuring airport service quality: a multidimensional approach", Journal of Air Transport Management, 53, pp. 85-93, http://dx.doi.org/10.1016/j.jairtraman.2016.02.001.

Fodness, D., \& Murray, B. (2007). Passengers' expectations of airport service quality. Journal of Services Marketing, 21(7), 492-506. http://doi.org/10.1108/08876040710824852

Fornell, C., \& Larcker, D. F. (1981). Evaluating structural equation models with unobservable variables and measurement error. Journal of Marketing Research, 18(1), 39-50.

Francis, G., Humphreys, I., \& Fry, J. (2002). The benchmarking of airport performance. Journal of Air Transport Management, 8(4), 239-247. http://doi.org/10.1016/S09696997(02)00003-0

George, B. P., Henthorne, T. L., \& Panko, T. R. (2013). ASQual: measuring tourist perceived service quality in an airport setting. International Journal of Business Excellence, 6(5), $526-536$.

Gillen, D. (2011). The evolution of airport ownership and governance. Journal of Air Transport Management, 17(1), 3-13. http://doi.org/10.1016/j.jairtraman.2010.10.003

Gkritza, K., Niemeier, D., \& Mannering, F. (2006). Airport security screening and changing passenger satisfaction: An exploratory assessment. Journal of Air Transport Management, 12(5), 213-219. http://doi.org/10.1016/j.jairtraman.2006.03.001

Gordon, H. G. M., \& Levesque, T. (2000). Customer satisfaction with services: putting perceived value into the equation. Journal of Services Marketing, 14(5), 392-410. Hackett, P., \& Foxall, G. (1997). Consumers' evaluations of an international airport: a facet theoretical approach. The International Review of Retail, Distribution and Consumer Research, 7(4), 339-349. http://doi.org/10.1080/095939697342923

Hair, J. F., Black, W. C., Babin, B. J., \& Anderson, R. E. (2009). Multivariate data analysis. New Jersey: Prentice Hall. 
Bezerra, G.C.L., \& Gomes, C.F. (2015) “Measuring airport service quality: a multidimensional approach", Journal of Air Transport Management, 53, pp. 85-93, http://dx.doi.org/10.1016/j.jairtraman.2016.02.001.

Halpern, N., \& Graham, A. (2013). Airport Marketing. New York: Routledge. Retrieved from http://books.google.com/books?hl=nI\&lr=\&id=MeHArNuqGkIC\&pgis=1

Horonjeff, R., Mckelvey, F. X., Sproule, W. J., \& Young, S. B. (2010). Planning and Design of Airports. New York: McGraw-Hill.

IATA, I. A. T. A. (2015). Iata Global Passenger Survey Highlights. Retrieved January 1, 2015, from www.iata.org/publications/Pages/global-passenger-survey.aspx

Jen, W., Lancaster, M., Hsieh, E., Wu, Y., \& Chan, S. (2013). Effects of Airport Servicescape on Passengers ' Satisfaction : A Hierarchical Approach and Importance-Performance Analysis. In Proceedings of the Eastern Asia Society for Transportation Studies, Vol. 9 (Vol. 9, pp. 1-12).

Jeon, S., \& Kim, M. S. (2012). The effect of the servicescape on customers' behavioral intentions in an international airport service environment. Service Business, 6(3), 279295.

Kramer, L. S., Bothner, A., \& Spiro, M. (2013). How Airports Measure Customer Service Performance: A synthesis of airport practice. ACRP Synthesis 48. Washington, D.C. Kuo, M. S., \& Liang, G. S. (2011). Combining VIKOR with GRA techniques to evaluate service quality of airports under fuzzy environment. Expert Systems with Applications, 38(3), 1304-1312. http://doi.org/10.1016/j.eswa.2010.07.003

Lemer, A. C. (1992). Measuring performance of airport passenger terminals. Transportation Research Part A: Policy and Practice, 26(1), 37-45.

Lubbe, B., Douglas, A., \& Zambellis, J. (2011). An application of the airport service quality model in South Africa. Journal of Air Transport Management, 17(4), 224-227. 
Bezerra, G.C.L., \& Gomes, C.F. (2015) “Measuring airport service quality: a multidimensional approach”, Journal of Air Transport Management, 53, pp. 85-93, http://dx.doi.org/10.1016/j.jairtraman.2016.02.001.

http://doi.org/10.1016/j.jairtraman.2010.08.001

Lupo, T. (2015). Fuzzy ServPerf model combined with ELECTRE III to comparatively evaluate service quality of international airports in Sicily. Journal of Air Transport Management, 42, 249-259. http://doi.org/10.1016/j.jairtraman.2014.11.006

Mari, M., \& Poggesi, S. (2011). Servicescape cues and customer behavior: a systematic literature review and research agenda. The Service Industries Journal, (June 2015), 129. http://doi.org/10.1080/02642069.2011.613934

Merkert, R., \& Assaf, A. G. (2015). Using DEA models to jointly estimate service quality perception and profitability - Evidence from international airports. Transportation Research Part A: Policy and Practice, 75, 42-50.

Mikulic, J., \& Prebežac, D. (2008). Prioritizing improvement of service attributes using impact range-performance analysis and impact-asymmetry analysis. Managing Service Quality, 18(6), 559-576. http://doi.org/10.1108/09604520810920068

Muller, C., \& Gosling, G. D. (1991). A framework for evaluating level of service for airport terminals. Transportation Planning and Technology, 16, 45-61.

Mumayiz, S. A. (1991). Evaluating performance and service measures for the airport landside. Transportation Research Record, 1296, 23-30.

Mumayiz, S. A., \& Ashford, N. (1986). Methodology for Planning and Operations Management of Airport Terminal Facilities. Transportation Research Record, 1094, 2435.

Nesset, E., \& Helgesen, $\varnothing$. (2014). Effects of switching costs on customer attitude loyalty to an airport in a multi-airport region. Transportation Research Part A: Policy and Practice, 
Bezerra, G.C.L., \& Gomes, C.F. (2015) “Measuring airport service quality: a multidimensional approach", Journal of Air Transport Management, 53, pp. 85-93, http://dx.doi.org/10.1016/j.jairtraman.2016.02.001.

67, 240-253. http://doi.org/10.1016/j.tra.2014.07.003

Omer, K. F., \& Khan, A. M. (1988). Airport Landside Level of Service Estimation: Utility

Theoretic Approach. Transportation Research Record, 1199, 33-40.

Pantouvakis, A. (2010). The relative importance of service features in explaining customer satisfaction: A comparison of measurement models. Managing Service Quality: An International Journal, 20(4), 366-387.

Park, J. W., \& Jung, S. Y. (2011). Transfer Passengers' Perceptions of Airport Service Quality: A Case Study of Incheon International Airport. International Business Research, 4(3), 75-82. http://doi.org/10.5539/ibr.v4n3p75

Park, Y. (1999). A methodology for establishing operational standards of airport passenger terminals. Journal of Air Transport Management, 5(2), 73-80.

http://doi.org/10.1016/S0969-6997(98)00040-4

Podsakoff, P. M., MacKenzie, S. B., Lee, J.-Y., \& Podsakoff, N. P. (2003). Common method biases in behavioral research: a critical review of the literature and recommended remedies. Journal of Applied Psychology, 88(5), 879-903.

Popovic, V., Kraal, B., \& Kirk, P. (2009). Passenger experience in an airport: an activitycentred approach. In IASDR 2009 Procedings (pp. 18-22). Seoul.

Prebezac, D., Mikulic, J., \& Jurkovic, P. (2010). Passenger perceptions of airport service performance: A three-dimensional importance-performance Analysis. Acta Turistica, 22(2), 161-177.

Ravald, A., \& Grönroos, C. (1996). The Value Concept and Relationship Marketing. European Journal of Marketing, 30(2), 19-30. 
Bezerra, G.C.L., \& Gomes, C.F. (2015) “Measuring airport service quality: a multidimensional approach", Journal of Air Transport Management, 53, pp. 85-93, http://dx.doi.org/10.1016/j.jairtraman.2016.02.001.

Rhoades, D. L., Waguespack Jr, B., \& Young, S. (2000). Research and concepts Developing a quality index for US airports. Managing Service Quality, 10(4), 257-262.

SAC, S. de A. C. (2015). Metodologia de Coleta de Dados de Desempenho Operacional dos Aeroportos/Processo Licitatório: Pregão n.3/2012 UASG110590. Brasília. Retrieved from http://www.aviacaocivil.gov.br/relatorio-geral-dos-indicadores/relatorio-geral-dosindicadores-de-desempenho-operacional

Sass, D. A. (2011). Testing measurement invariance and comparing latent factor means within a confirmatory factor analysis framework. Journal of Psychoeducational Assessment, 29(4), 347-363.

Seneviratne, P. N., \& Martel, N. (1991). Variables influencing performance of air terminal buildings. Transportation Planning and Technology, 16(1), 1177-1179.

Seneviratne, P. N., \& Martel, N. (1994). Criteria for evaluating quality of service in air terminals. Transportation Research Record, 1461, 24-30.

Tosic, V., \& Babic, O. (1984). Quantitative evaluation of passenger terminal orientation. Journal of Advanced Transportation, 18, 279-295.

Tsai, W.-H., Hsu, W., \& Chou, W.-C. (2011). A gap analysis model for improving airport service quality. Total Quality Management \& Business Excellence, 22(10), 1025-1040. http://doi.org/10.1080/14783363.2011.611326

Wilson, A., Zeithaml, V. A., Bitner, M. J., \& Gremler, D. D. (2012). Services marketing: integrating customer focus across the firm (2nd ed.). Berkshire: McGraw-Hill.

Yeh, C.-H., \& Kuo, Y.-L. (2003). Evaluating passenger services of Asia-Pacific international airports. Transportation Research Part E: Logistics and Transportation Review, 39(1), 
Bezerra, G.C.L., \& Gomes, C.F. (2015) “Measuring airport service quality: a multidimensional approach", Journal of Air Transport Management, 53, pp. 85-93, http://dx.doi.org/10.1016/j.jairtraman.2016.02.001.

35-48. http://doi.org/10.1016/S1366-5545(02)00017-0

Yen, J. R. (1995). A new approach to measure the level of service of procedures in the airport landside. Transportation Planning Journal, 24(3), 323-336.

Zidarova, E. D., \& Zografos, K. G. (2011). Measuring Quality of Service in Airport Passenger Terminals. Transportation Research Record: Journal of the Transportation Research Board, 2214, 69-76. 
Bezerra, G.C.L., \& Gomes, C.F. (2015) “Measuring airport service quality: a multidimensional approach”, Journal of Air Transport Management, 53, pp. 85-93, http://dx.doi.org/10.1016/j.jairtraman.2016.02.001.

\section{APPENDIX A}

Table A.1. Sample characteristics

\begin{tabular}{|c|c|c|c|c|}
\hline \multirow[b]{2}{*}{ Nationality } & \multicolumn{2}{|c|}{ International } & \multicolumn{2}{|c|}{ Domestic } \\
\hline & Freq. & $\%$ & Freq. & $\%$ \\
\hline Brazilian & 683 & 94,6 & 370 & 94,1 \\
\hline Other & 39 & 5,4 & 23 & 5,9 \\
\hline Total & 722 & 100,0 & 393 & 100,0 \\
\hline Gender & Freq. & $\%$ & Freq. & $\%$ \\
\hline Male & 346 & 47,9 & 234 & 59,5 \\
\hline Female & 376 & 52,1 & 159 & 40,5 \\
\hline Total & 722 & 100,0 & 393 & 100,0 \\
\hline Travel frequency & Freq. & $\%$ & Freq. & $\%$ \\
\hline 0 to 2 trips & 79 & 10,9 & 164 & 41,7 \\
\hline 3 to 5 trips & 395 & 54,7 & 136 & 34,6 \\
\hline$>5$ trips & 248 & 34,3 & 93 & 23,7 \\
\hline Total & 722 & 100,0 & 393 & 100,0 \\
\hline Trip purpose & Freq. & $\%$ & Freq. & $\%$ \\
\hline $\begin{array}{l}\text { No business (Includes leisure and other } \\
\text { purposes) }\end{array}$ & 442 & 61,2 & 252 & 64,1 \\
\hline Business & 279 & 38,6 & 141 & 35,9 \\
\hline Total & 722 & 100,0 & 393 & 100,0 \\
\hline Antecedence of arrival at the airport & Freq. & $\%$ & Freq. & $\%$ \\
\hline Less than 1 hour & 2 & 0,3 & 59 & 15,0 \\
\hline Equal or more than 1 hour and less than 2 hours & 27 & 3,7 & 189 & 48,1 \\
\hline $\begin{array}{l}\text { Equal or more than } 2 \text { hours and less than } 3 \\
\text { hours }\end{array}$ & 187 & 25,9 & 74 & 18,8 \\
\hline Equal or more than 3 hours & 506 & 70,1 & 71 & 18,1 \\
\hline Total & 722 & 100,0 & 393 & 100,0 \\
\hline
\end{tabular}


Bezerra, G.C.L., \& Gomes, C.F. (2015) “Measuring airport service quality: a multidimensional approach”, Journal of Air Transport Management, 53, pp. 85-93, http://dx.doi.org/10.1016/j.jairtraman.2016.02.001.

\section{Appendix B. Airport service quality factors}

Table B.1. Description of the ASQ factors

\begin{tabular}{|c|c|}
\hline Factors & Comments \\
\hline Check-in & $\begin{array}{l}\text { Includes typical service performance indicators, such as passengers' perceptions related } \\
\text { to wait-time, process efficiency and attitude of service staff. }\end{array}$ \\
\hline Security & $\begin{array}{l}\text { Comprises wait-time and attitude of service staff. Includes the thoroughness of security } \\
\text { screening and passenger's feeling of safety, which are aspects of a wider perception of } \\
\text { ASQ. }\end{array}$ \\
\hline Convenience & $\begin{array}{l}\text { Reflects on the availability and quality of convenient facilities and services. As } \\
\text { commercial revenues are critical for airport sustainability, providing alternatives for } \\
\text { passengers enjoying their free time is a very important issue. As regards future } \\
\text { developments, other items should be included to provide a more comprehensive } \\
\text { indication of passengers' perceptions regarding this ASQ factor. }\end{array}$ \\
\hline Ambience & $\begin{array}{l}\text { Comprises the environmental surroundings of airport terminal, including thermal and } \\
\text { acoustic comfort, and airport facilities cleanliness. The airport physical environment is } \\
\text { nonetheless critical for passenger's evaluation on ASQ. Researches have tried to provide } \\
\text { further understanding on how it is perceived and how it can affect passengers' } \\
\text { satisfaction (Fodness \& Murray, 2007; Jen et al., 2013; Jeon \& Kim, 2012). Developments } \\
\text { should embrace outcomes arising from these studies and others. }\end{array}$ \\
\hline Basic Facilities & $\begin{array}{l}\text { Differentiates from the Ambience for comprising items associated with the satisfaction } \\
\text { of the most basic passengers' needs during their stay at the airport. Washroom facilities } \\
\text { availability and cleanliness, as well as departure lounge facilities, are basic elements for } \\
\text { airport design (Horonjeff et al., 2010) and are typical examples of dissatisfiers as } \\
\text { assumed as prerequisites for airport service performance (Mikulic \& Prebežac, 2008). }\end{array}$ \\
\hline Mobility & $\begin{array}{l}\text { Comprises aspects related to wayfinding, flight information and the walking distance } \\
\text { inside the terminal. Mobility is always a major concern for airport design and operations. } \\
\text { Proper mobility solutions may help minimize the time and uncertainty for passengers } \\
\text { when moving within the terminal and allow passengers to stay more relaxed at their } \\
\text { interaction with the airport setting. }\end{array}$ \\
\hline
\end{tabular}


Bezerra, G.C.L., \& Gomes, C.F. (2015) “Measuring airport service quality: a multidimensional approach", Journal of Air Transport Management, 53, pp. 85-93, http://dx.doi.org/10.1016/j.jairtraman.2016.02.001.

\section{Appendix C. CFA estimates}

\section{Table C.1. Standardized regression weights}

\begin{tabular}{|c|c|c|c|c|}
\hline Estimates & & & $\begin{array}{c}\text { International } \\
\text { Passengers }\end{array}$ & $\begin{array}{c}\text { Domestic } \\
\text { Passengers }\end{array}$ \\
\hline CHK1 - Courtesy and helpfulness of check-in staff & $<---$ & Check_in & ,916* & ,917* \\
\hline CHK2 - Check-in process efficiency & $<---$ & Check_in & ,974* & ,933* \\
\hline CHK4 - Wait time at check-in & $<---$ & Check_in & ,804* & ,667* \\
\hline SEC1 - Feeling of being safe and secure & $<---$ & Security & ,849* & ,693* \\
\hline SEC2 - Courtesy and helpfulness of security staff & $<---$ & Security &, $827^{*}$ & ,823* \\
\hline SEC3 - Thoroughness of security screening & $<---$ & Security & ,928* & ,819* \\
\hline SEC4- Wait-time at security checkpoints & $<---$ & Security & ,919* & ,798* \\
\hline CON2 - Availability and quality of stores & $<---$ & Convenience & ,923* & $688^{*}$ \\
\hline CON3 - Availability of Banks/ATM/Exchange & $<---$ & Convenience & $878^{*}$ & ,784* \\
\hline CON4 - Availability and quality of food facilities & $<---$ & Convenience &, $659 *$ &, $654^{*}$ \\
\hline AMB1 - Cleanliness of airport facilities & $<---$ & Ambience &, $677^{*}$ & ,803* \\
\hline AMB2 - Thermal comfort & $<---$ & Ambience & ,934* & ,803* \\
\hline AMB3 - Acoustic comfort & $<---$ & Ambience & $891^{*}$ & ,833* \\
\hline BAS1- Cleanliness of washroom/toilets & $<---$ & Basic_Facilities & ,933* &, $863^{*}$ \\
\hline BAS2 - Availability of washroom/toilets & $<---$ & Basic_Facilities &, $891^{*}$ &, $825^{*}$ \\
\hline BAS3 - Departure lounge comfort & $<---$ & Basic_Facilities & ,900* & ,688* \\
\hline MOB1 - Walking distance inside terminal & $<---$ & Mobility & ,899* & ,736* \\
\hline MOB2 - Wayfinding & $<---$ & Mobility & ,789* & ,839* \\
\hline MOB3 - Flight information & $<---$ & Mobility & ,956* & ,788* \\
\hline
\end{tabular}

Note: *Significant at <.001 level.

Table C.2. Correlations

\begin{tabular}{|llcc|}
\hline & Estimates & $\begin{array}{c}\text { International } \\
\text { Passengers }\end{array}$ & $\begin{array}{c}\text { Domestic } \\
\text { Passengers }\end{array}$ \\
\hline Check_in & <--> Security &, $494^{*}$ &, $622^{*}$ \\
Check_in & <-> Convenience &, $240^{*}$ &, $407^{*}$ \\
Check_in & <--> Ambience &, $281^{*}$ &, $500^{*}$ \\
Check_in & <-> Basic_Facilities &, 060 &, $324^{*}$ \\
Check_in & $<-->$ Mobility &, $346^{*}$ &, $421^{*}$ \\
Security & $<->$ Convenience &, $404^{*}$ &, $538^{*}$ \\
Security & $<->$ Ambience &, $460^{*}$ &, $596^{*}$ \\
Security & $<->$ Basic_Facilities &, $332^{*}$ &, $463^{*}$ \\
Security & $<-->$ Mobility &, $569^{*}$ &, $677^{*}$ \\
Convenience & $<-->$ Ambience &, $531^{*}$ &, $603^{*}$ \\
Convenience & $<-->$ Basic_Facilities &, $583^{*}$ &, $630^{*}$ \\
Convenience & $<->$ Mobility &, $372^{*}$ &, $529^{*}$ \\
Ambience & $<-->$ Basic_Facilities &, $629^{*}$ &, $712^{*}$ \\
Ambience & $<-->$ Mobility &, $446^{*}$ &, $522^{*}$ \\
Basic_Facilities & $<-->$ Mobility &, $355^{*}$ &, $499^{*}$ \\
\hline
\end{tabular}

Note: *Significant at $<.001$ level. 
Bezerra, G.C.L., \& Gomes, C.F. (2015) “Measuring airport service quality: a multidimensional approach", Journal of Air Transport Management, 53, pp. 85-93, http://dx.doi.org/10.1016/j.jairtraman.2016.02.001.

TABLE 1. MEASUREMENT ITEMS DESCRIPTIVE

\begin{tabular}{|c|c|c|c|c|c|c|}
\hline \multirow{2}{*}{ Variables } & \multicolumn{3}{|c|}{ International passengers } & \multicolumn{3}{|c|}{ Domestic passengers } \\
\hline & Mean & SE & SD & Mean & SE & SD \\
\hline Courtesy and helpfulness of check-in staff & 3,53 & ,039 & 1,043 & 4,13 & ,047 & ,923 \\
\hline Check-in process efficiency & 3,55 & 036 & ,976 & 4,11 & 044 & 874 \\
\hline Availability of luggage carts & 3,16 & ,053 & 1,416 & 4,14 & ,065 & 1,073 \\
\hline Wait time at check-in & 3,46 & 039 & 1,061 & 3,88 & ,050 & ,988 \\
\hline Feeling of being safe and secure & 3,43 & ,034 & ,910 & 3,87 & ,045 & ,895 \\
\hline Courtesy and helpfulness of security staff & 3,57 & ,032 & 871 & 4,07 & ,040 & ,802 \\
\hline Thoroughness of security screening & 3,54 & 034 & ,913 & 3,96 & ,043 & ,852 \\
\hline Wait-time at security checkpoints & 3,56 & 034 & ,909 & 4,05 & ,042 & ,834 \\
\hline Courtesy and helpfulness of airport staff* & 3,37 & 039 & 1,055 & 4,10 & 044 & ,848 \\
\hline Availability and quality of stores & 2,84 & ,041 & 1,110 & 3,45 & ,058 & 1,144 \\
\hline Availability of Banks/ATM/Exchange & 2,85 & ,040 & 1,076 & 3,62 & 055 & 1,094 \\
\hline Availability and quality of food facilities & 2,55 & ,044 & 1,176 & 3,45 & 058 & 1,144 \\
\hline Cleanliness of airport facilities & 3,13 & ,032 & ,857 & 3,95 & ,042 & ,835 \\
\hline Thermal comfort & 3,16 & ,033 & 898 & 3,86 & ,044 & ,879 \\
\hline Acoustic comfort & 3,10 & ,034 & ,927 & 3,82 & ,046 & 918 \\
\hline Cleanliness of washroom/toilets & 3,06 & ,044 & 1,173 & 3,79 & 052 & 1,040 \\
\hline Availability of washroom/toilets & 3,11 & ,044 & 1,195 & 3,86 & ,053 & 1,045 \\
\hline Departure lounge comfort & 3,02 & ,041 & 1,111 & 3,58 & ,055 & 1,097 \\
\hline Walking distance inside terminal & 3,27 & ,037 & ,986 & 3,67 & 052 & 1,027 \\
\hline Wayfinding & 3,36 & ,034 & ,908 & 3,84 & ,048 & ,947 \\
\hline Flight information & 3,36 & ,036 & ,962 & 3,81 & ,047 & ,934 \\
\hline Prices at food facilities & 1,87 & ,036 & ,960 & 2,37 & ,063 & 1,251 \\
\hline Prices at stores & 2,35 & 041 & 1,110 & 2,56 &, 064 & 1,233 \\
\hline
\end{tabular}

Notes: SE - Standard error; SD - Standard deviation; *excluding check-in and security staff. 


\section{TABLE 2. EFA RESULTS FOR INTERNATIONAL DEPARTING PASSENGERS}

\begin{tabular}{|c|c|c|c|c|c|}
\hline Factors and observed variables & $\alpha$ & $\begin{array}{c}\alpha \text { if item } \\
\text { deleted }\end{array}$ & $\begin{array}{l}\text { Item-total } \\
\text { correlation }\end{array}$ & KMO & $\begin{array}{c}\% \text { variance } \\
\text { extracted }\end{array}$ \\
\hline CHK - Check in & .873 & & & .767 & 73.403 \\
\hline CHK1 - Courtesy and helpfulness of check-in staff & & .765 & .801 & & \\
\hline CHK2 - Check-in process efficiency & & .761 & .828 & & \\
\hline CHK3 - Availability of luggage carts & & .922 & .497 & & \\
\hline CHK4 - Wait-time at check-in & & .791 & .737 & & \\
\hline SEC - Security & .931 & & & .844 & 83.009 \\
\hline SEC1 - Feeling of being safe and secure & & .920 & .812 & & \\
\hline SEC2 - Courtesy and helpfulness of security staff & & .927 & .787 & & \\
\hline SEC3 - Thoroughness of security screening & & .896 & .883 & & \\
\hline SEC4- Wait-time at security checkpoints & & .899 & .876 & & \\
\hline CON - Convenience & .840 & & & .725 & 67.862 \\
\hline CON1 - Courtesy and helpfulness of airport staff & & .850 & .546 & & \\
\hline CON2 - Availability and quality of stores & & .762 & .752 & & \\
\hline CON3 - Availability of Banks/ATM/Exchange & & .778 & .720 & & \\
\hline CON4 - Availability and quality of food facilities & & .793 & .684 & & \\
\hline AMB - Ambience & .865 & & & .677 & 78.982 \\
\hline AMB1 - Cleanliness of airport facilities & & .911 & .629 & & \\
\hline AMB2 - Thermal comfort & & .730 & .831 & & \\
\hline AMB3 - Acoustic comfort & & .773 & .786 & & \\
\hline BAS - Basic Facilities & .933 & & & .763 & 88.230 \\
\hline BAS1- Cleanliness of washroom/toilets & & .886 & .883 & & \\
\hline BAS2 - Availability of washroom/toilets & & .912 & .850 & & \\
\hline BAS3 - Departure lounge comfort & & .909 & .855 & & \\
\hline MOB - Mobility & .909 & & & .715 & 84.652 \\
\hline MOB1 - Walking distance inside terminal & & .855 & .836 & & \\
\hline MOB2 - Wayfinding & & .927 & .746 & & \\
\hline MOB3 - Flight information & & .817 & .879 & & \\
\hline PRC - Price & .650 & & & .500 & 74.051 \\
\hline PRC1 - Prices at food facilities & & NC & .481 & & \\
\hline PRC2 - Prices at stores & & NC & .481 & & \\
\hline
\end{tabular}

Note: a. $\alpha$-Cronbach's Alpha; b. Bartlett's Test of Sphericity with statistical significance $<001$ for all factors. 
TABLE 3. PEARSON'S COEFFICIENT OF CORRELATIONS, CRONBACH'S ALPHA, AND FACTORIAL VALIDITY AND RELIABILITY

\begin{tabular}{|lccccccccc|}
\hline & CHK & SEC & MOB & AMB & BAS & CON & $\alpha$ & CR & AVE \\
\hline Check-in - CHK & .901 & & & & & & .922 & .928 & .811 \\
Security - SEC & $.494^{*}$ & .882 & & & & & .931 & .933 & .778 \\
Mobility - MOB & $.346^{*}$ & $.569^{*}$ & .884 & & & & .909 & .914 & .782 \\
Ambience - AMB & $.281^{*}$ & $.460^{*}$ & $.446^{*}$ & .842 & & & .865 & .877 & .708 \\
Basic facilities - BAS & .060 & $.332^{*}$ & $.355^{*}$ & $.629 *$ & .908 & & .933 & .934 & .825 \\
Convenience - CON & $.240^{*}$ & $.404^{*}$ & $.372^{*}$ & $.531^{*}$ & $.583^{*}$ & .828 & .850 & .865 & .686 \\
\hline
\end{tabular}

Notes: In the diagonal values for the square root of the AVE; *Significance level <.001 for the correlations; $\alpha-$ Cronbach's Alpha; CR - Composite Reliability; AVE - Average Extracted Variance.

\section{TABLE 4. MODELS COMPARISON}

\begin{tabular}{|l|rrr|}
\hline Model & CMIN & DF & CFI \\
\hline Unconstrained & 795,140 & 274 & .967 \\
1. Factor Loadings constrained & 849,252 & 287 & .964 \\
2. Factor Loadings and covariance constrained & 880.741 & 302 & .963 \\
\hline
\end{tabular}

Note: Assuming model unconstrained to be correct. 
FIGURE 1. CFA MODEL OUTPUT FOR INTERNATIONAL DEPARTING PASSENGERS

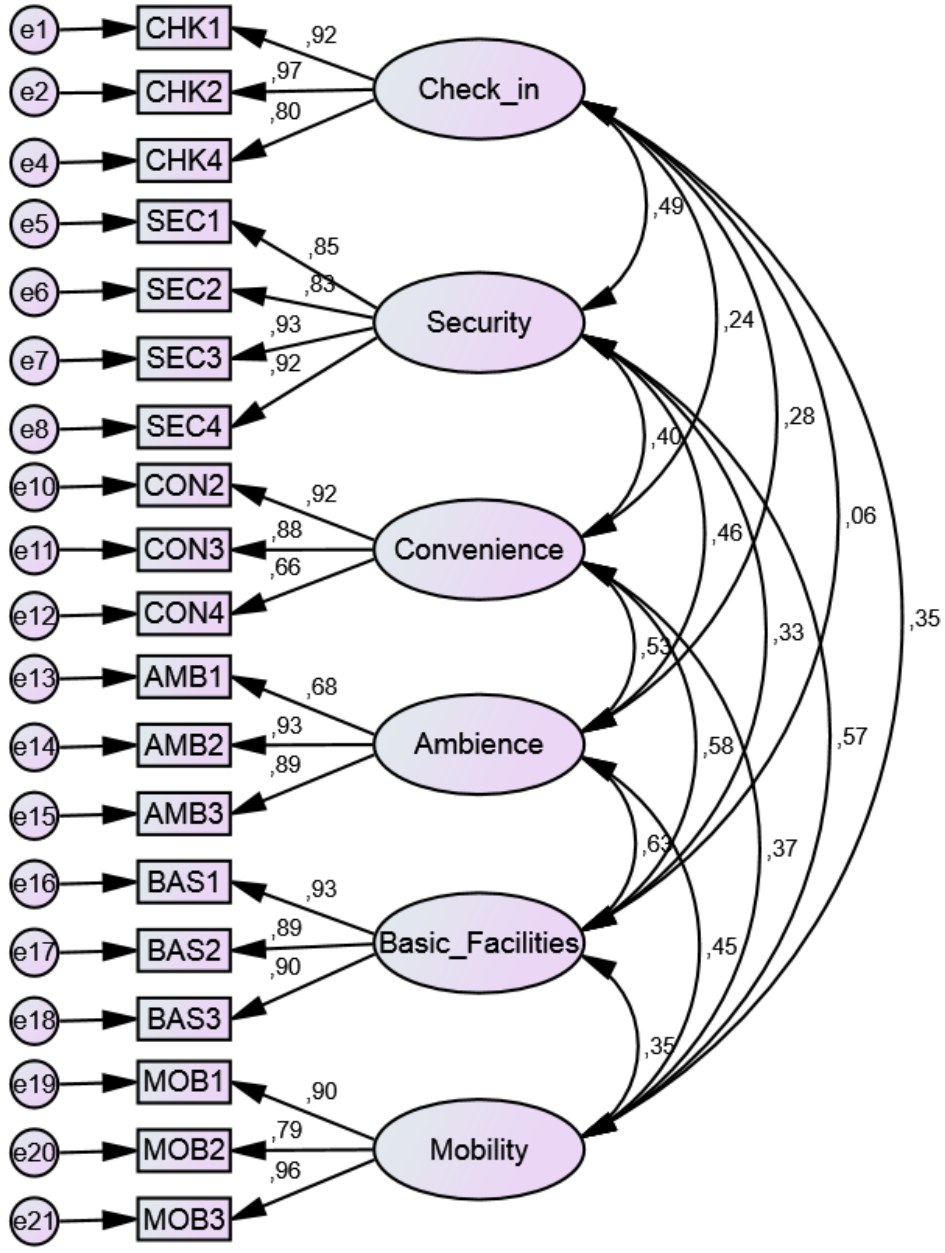

